\title{
Konstelasi Pemikiran Hukum HAM Historis dan Pengaruhnya Terhadap Instrumentasi Hukum HAM Pasca Reformasi
}

\author{
M. Syafi'ie \\ Fakultas Hukum Universitas Islam Indonesia \\ E-mail:m.syafiie@uii.ac.id
}

\begin{abstract}
Human rights instruments are not in a vacuum. The rules are heavily influenced by social constellation, influenced by injustice and humanity violations. The emergence of an instrument of human rights law originating from the struggle of the people representing the victims is often inconsistent with the power that politically requires the restriction and reduction of human rights. This paper provides an overview of how the instruments of human rights law in Indonesia are fought for, manifested and the face of its legal products that always show a tug-of-war between the power of society and power.
\end{abstract}

Keywords: Constellation of Law, Human Rights, Post Reformation

\begin{abstract}
Abstrak
Instrumen hukum HAM tidak berada dalam ruang hampa. Peraturan tersebut sangat dipengaruhi oleh konstelasi sosial, dipengaruhi oleh ketidakadilan dan pelanggaran kemanusaan yang terjadi. Kemunculan instrumen hukum HAM yang berasal dari perjuangan rakyat yang mewakili korban seringkali tidak sejalan dengan kekuasaan yang secara politik menghendaki pembatasan dan pengurangan terhadap HAM. Tulisan ini memberi gambaran memanjang bagaimana instrumen hukum HAM di Indonesia diperjuangkan, diwujudkan dan wajah produk hukumnya yang selalu memperlihatkan tarik menarik antara kekuatan masyarakat dan kekuasaan.
\end{abstract}

Kata Kunci: Konstelasi Hukum, HAM, Pasca Reformasi 


\section{A. Pendahuluan}

Instrmentasi HAM dalam berbagai perundang-undangan di Indonesia pasca reformasi kalau kita baca secara historis, gagasan ini tidaklah lahir secara tiba-tiba melainkan dilatar belakangi oleh konstelasi pemikiran hukum HAM dan gejolak sosial dalam fase-fase sebelum dan pasca kemerdekaan. Konstelasi pemikiran hukum HAM nasional ataupun internasional mempengaruhi terhadap produk-produk hukum yang dilahirkan, sedangkan di sisi yang lain terdapat fakta-fakta sosial yang terus-menerus dalam dilema.

Di era orde lama, instrumentasi HAM mengalami progresifitas pemikiran hukum HAM yang cukup tinggi, mulai pembahasan instrumentasi HAM dalam UUD 1945, konstitusi RIS dan UUDS 1950. Penghargaan terhadap HAM di era orde lama berlangsung cukup bagus, partai-partai politik dengan berbagai macam ideologinya berdiri, kebebasan pers dijamin, pemilu berlangsung dengan penuh nuansa kebebasan, sangat demokratis dan fair, parlemen berfungsi sebagai kontrol sangat kuat terhadap kekuasaan pemerintahan.

Nuansa penghormatan terhadap HAM berlangsung cukup meyakinkan di era orde lama karena pengaruh sosiologis konstelasi pemikiran hukum HAM nasional yang berkembang cukup dinamis menjelang kemerdekaan Indonesia serta pengaruh konstelasi pemikiran hukum HAM internasional pasca perang dunia II yang menelan korban manusia yang tidak sedikit. Penghormatan terhadap HAM mengalami kemacetan diawali ketika Soekarno memberlakukan demokrasi terpimpin dan mengekang hakhak yang seharusnya dijamin oleh negara.

Demokrasi terpimpin mendapatkan gugatan yang massif dari masyarakat sedangkan di sisi yang lain terdapat fakta pelanggaran HAM dalam peristiwa G30S/PKI. Soekarno akhirnya jatuh tahun 1966 setelah pemerintahannya dianggap 
gagal oleh MPRS dan digantikan oleh Soeharto yang waktu itu mendapatkan mandat Super Semar dari Soekarno. Sebagai pemerintahan yang baru setelah dipilih oleh MPRS, Soeharto menyebut pemerintahannya sebagai orde baru dan berjanji untuk menegakkan kembali UUD 1945 secara murni, konsekwen dan akan melaksanakan politik pembangunan dalam kepemimpinannya.

Janji-janji Soeharto yang awalnya manis juga berujung pada diktatorian yang lebih kejam dibanding demokrasi terpimpin Seokarno. Soeharto membangun sistem kenegaraan yang monolitik dan tersentrum pada titah Soeharto yang tunggal. Di era kepemimpinanannya, pemikran dan instrumentasi HAM mengalami krisis yang sangat total sedangkan di sisi yang lain muncul berbagai pelanggaran HAM negara dan produk-produk hukum yang sangat diskriminatif. Muatan-muatan HAM yang ada dalam UUD 1945, diintrodusir sedemikian sistemik untuk membenarkan kebijakan-kebijakan Soeharto yang otoritarian.

Praktek politik dan hukum yang secara substantif melanggar HAM, dan dibarengi dengan tindakan-tindakan pelanggaran HAM berat yang terjadi di berbagai daerah di era Soeharto melahirkan gugatan-gugatan sosial yang sangat besar. Gugatan itu tidak hanya bersumber dari korban-korban pelanggaran HAM yang ada di Indonesia, tetapi juga dari masyarakat dan badan internasional. Gugatan yang bersumber dari berbagai lapisan masyarakat itu membuat rezim orde baru tersudutkan dan "terpaksa" dalam skala kecil melakukan instrumentasi HAM.

Situasi rezim orde baru yang terjebak dalam dosa-dosa pelanggaran dan perselingkuhannya yang teramat besar mendorong kejatuhannya. Beban pelanggaran HAM berat orde baru meniscayakan instrumentasi HAM pasca kejatuhannya, yang harapannya menjadi landasan konstitusional penegakan hukum HAM untuk peristiwa 
pelanggaran HAM masa lalu dan menjamin pemenuhan HAM di masa depan.

Berangkat dari pemikiran di atas, analisa instrumentasi hukum HAM pasca reformasi tidak akan lepas dari historis dan sosiologis yang memanjang dan bertemali dari satu satu rezim ke rezim sesudahnya. Tulisan ini hendak mengelaborasi instrumentasi hukum HAM pasca reformasi dengan berbagai kontelasi pemikiran hukum HAM secara historis dan fakta-fakta sosial yang melatarbelakanginya.

\section{B. Konstelasi Pemikiran Hukum HAM Historis}

Historisitas pemikiran hukum HAM di Indoneisa, tidak bisa dilepaskan dari suasana pemikiran HAM dalam pergerakan perjuangan nasional sebelum kemerdekaan, pemikiran hukum HAM rezim orde lama dan pemikiran hukum HAM orde baru. Berbagai pemikiran hukum HAM historis dalam fase-fase tersebut memiliki fakta-fakta sosial tersendiri.

\section{Konstelasi Pemikiran Hukum HAM Sebelum Kemerdekaan}

Kekalahan Rusia atas Jepang dalam peperangan sekitar laut kuning tahun 1905 membangkitkan kesadaran baru bahwa kemampuan kulit kuning tidak berada di bawah bangsa kulit putih. Kemenangan Jepang tersebut mempengaruhi pandangan-pandangan kaum intelektual Hindia Belanda mengenai kemampuan pribumi untuk melepaskan diri dari penjajahan dan memproklamasikan hak kemerdekaan. ${ }^{1}$

Sekitar tanggal 20 Mei 1908 pelajar-pelajar STOVIA yang bercita-cita meningkatkan kedudukan dan martabat rakyat berkumpul di gedung STOVIA dan mendeklasikan

${ }^{1}$ Bagir Manan, Perkembangan Pemikiran dan Pengaturan HAM di Indonesia, Yayasan Hak Asasi Manusia, Demokrasi dan Supremasi Hukum, Bandung, 2001, hlm xiii-xiv 
berdirinya organisasi Boedi Oetomo yang diketua Soetomo. Pendirian organisasi ini dipandang banyak pihak sebagai cikal bakal pergerakan nasional untuk mencapai kemerdekaan. Dalam kurun waktu semenjak tahun 19081945 terjadi pergolakan pemikiran hak asasi manusia yang terungkap dalam pemikiran para tokoh pada waktu itu.

Setelah pecah perang dunia I tahun 1914, pergerakan Boedi Oetomo menggalakkan diskusi-diskusi yang diadakan para angotanya. Salah satu gagasan organisasi Boedi Oetomo untuk mewujudkan kesetaraan hak-hak pribumi ialah perlu diwujudkan perwakilan rakyat. Untuk mewujudkan gagasannya, organisasi ini mengirimkan delegasi ke Negeri Belanda dan bertemu dengan pemimpin-pemimpin Belanda. Salah satu hasilnya ialah dipertimbangkannya pendirian Volksraad dan kemudian pada tahun 1916 disetujui menjadi Undang-Undang. ${ }^{2}$

Setalah dilakukan pemilihan Volksraad, organisasi Boedi Oetomo memperoleh hasil kursi nomor dua besarnya di antara anggota pribumi. Hasil yang signifikan tersebut membangkitkan kesadaran organisasi Boedi Oetomo tentang perlunya penggalangan massa. Situasi ini ditanggapi dengan politik keras oleh Gubernur Jenderal Mr. D. Fock melalui pengurangan anggaran pendidikan sehingga terjadi perpecahan di dalamnya dan berakhir setelah fusi ke dalam partai Partai Indonesia Raya (Perindra) tahun $1935 .^{3}$ Kesadaran berserikat dan mengeluarkan pendapat melalui petisi dan tulisan-tulisan yang ditujukan kepada pemerintah Kolonial sudah berkembang dengan baik.

Demikian juga organisasi Perhimpunan Indonesia yang didirikan oleh mahasiswa Indonesia di Belanda tahun 1908. Organisasi ini awalnya bersifat sosial tetapi berubah menjadi pergerakan politik anti imprealisme dan kolonialisme pasca

2 Sartono Kartodirjo, (et.al), Sejarah Nasional Indonesia V, Departemen Pendidikan dan Kebudayaan, Jakarta, 1975, hlm 178

${ }^{3}$ Ibid, hlm 181 
berakhirnya perang dunia I. Organisasi ini membangun kesadaran tentang hak menentukan nasib sendiri (the right of self determination) dan merdeka dari penjajahan Belanda. Untuk mencapai tujuannya organisasi ini mengadakan hubungan dengan organisasi internasional lainnya seperti Liga Penentang Imprealisme dan Penindasan Kolonial, Komintern dan lain-lain. Pada Kongres Ke-16 Liga Demokrasi Internasional untuk perdamaian di Paris tahun 1926, Moh. Hatta sangat tegas menyatakan tuntutan untuk kemerdekaan Indonesia. ${ }^{4}$

Pada tahun 1911 juga berdiri organisasi pribumi bernama Sarekat Islam di daerah Solo. Pendirian organisasi ini didasari oleh kepentingan bersama untuk melawan terhadap dagang antara (penyalur) oleh orang -orang Cina yang dianggap melakukan penindasan dan telah melakukan kesombongan rasial. Tujuan dasar dari organisasi ini ialah mengembangkan jiwa berdagang, memberi bantuan kepada anggotanya yang menderita kesukaran, memajukan pengajaran dan semua yang mempercepat naiknya derajat bumi putera dan menentang pendapat yang keliru tentang agama Islam. ${ }^{5}$

Organisasi Sarekat Islam merupakan organisasi massa pertama pasca Boedi Oetomo yang didominiasi oleh para priyayi dan ambtenar. Serekat Islam merupakan organisasi yang membumi dan mengakar di masyarakat. Corak organisasi Sarekat Islam ialah pemikirannya yang cenderung marxis dan radikal. Secara umum konsepsi pemikiran HAM yang dikemukakan organisasi Sarekat Islam ialah hak untuk memperolah penghidupan yang layak, bebas dari penindasan dan bebas dari diskriminasi rasial.

Pasca Serikat Islam muncul organisasi politik, Partai Komunis Indonesia (PKI) yang melandaskan perjuangannya

\footnotetext{
${ }^{4}$ Wangsa I Wijaya, Mengenang Bung Hatta, CV Haji Masaagung, Jakarta, 1988, hlm 32

${ }^{5}$ Sartono Kartodirjo, (et.al), Sejarah Nasional Indonesia, hlm 183
} 
pada ideologi marxisme. Hak-hak yang diperjuangkan PKI ialah berdimensi HAM yang bersifat sosial dan berkaitan dengan diskursus keadilan kepemilikan produksi, distribusi dan modal. Kenggotaan PKI didominasi oleh kaum buruh, pekerja-pekerja pertanian, kuli dan kaum buruh pertanian.

Organisasi-organisasi di atas menandai fase-fase perjuangan HAM di Indonesia, Boedi Oetomo penanda dari lahirnya kesadaran nasional, Sarekat Islam merupakan fondasi lahirnya organisasi revolusioner sedangkan fase ketiga ialah bercorak politik dan penyusunan program kemerdekaan nasional. Pada fase ketiga ini muncul organisasi seperit Indische Partij yang menegaskan tujuannya untuk membangun patriotisme semua "indier" terhadap tanah air dan memberi lapangan hidup kepada mereka , agar mereka mendapat dorongan untuk bekerjasama atas dasar persamaan ketatanegaraan untuk memajukan tanah air "Hindia" dan untuk mempersiapkan kehidupan rakyat yang merdeka.

Tujuan organisasi yang sedemikian tegas ini mengakibatkan permohonan organisasi ini untuk menjadi badan hukum ditolak oleh pemerintah Belanda dengan alasan organisasi ini berdasarkan politik dan mengancam hendak merusak keamanan umum. ${ }^{6}$ Indische Partij menjadi partai terlarang dan redup setelah para pemimpinnya Douewes Dekker, Suwardi Surjanigrat dan dr. Tjipto Mangunkusomo dijatuhi hukuman buangan. Konsepsi HAM dalam Indische Partij adalah memperjuangkan untuk mendapatkan hak kemerdekaan serta mendapatkan perlakuan yang setara (non discrimination).

Setelah Indische Partij, muncul Partai Nasional Indonesia yang menegaskan tujuannya untuk memperjuangkan kemerdekaan politik yang berarti berhentinya pemerintahan kolonial Belanda. ${ }^{7}$ Kemerdekaan

\footnotetext{
${ }^{6}$ Ibid, hlm 188

${ }^{7}$ Ibid, hlm 212
} 
Indonesia menjadi syarat utama untuk memperbaiki kembali susunan masyarakat Indonesia yang telah rusak akibat adanya imprealisme. Pemikiran HAM, Partai Nasional Indonesia yang banyak dipengaruhi pemikiran Soekarno mengorentasikan untuk mendapatkan kemerdekaan (the right of self determination) yaitu perwujudan suatu sosiodemokrasi yang diwadahi oleh negara yang demokratis.

Setelah tokoh PNI Soekarno ditangkap tahun 1931 dan berdasarkan hasil kongres luar biasa ke-2 di Jakarta Partai Nasioanal Indonesia dibubarkan. Sebagai bentuk kekecewaan akhirnya didirikanlah Pendidikan Nasional Indonesia oleh Moh. Hatta yang bertujuan untuk memperjuangkan kemerdekaan politik dengan mengutamakan program pendidikan politik, ekonomi dan sosial yang dilaksanakan dengan taktik non-kooperatif.

Asas Pendidikan Nasional Indonesia ialah kebangsaan dan kerakyatan. Menurut Moh Hatta asas kebangsaan ditetapkan karena akan menuju Indonesia merdeka yakni kemerdekaan bangsa dan tanah air dan tidak ada pergerakan kemerdekaan tanpa semangat kebangsaan. Asas kebangsaan dimaksudkan untuk melepaskan posisi feodalisme ningrat ataupun intelektual melainkan kebangsaan untuk rakyat. ${ }^{8}$

Pemikiran HAM Moh Hatta dalam organisasi Pendidikan Nasional Indonesia tidak jauh berbeda dengan pemikiran Soekarno. HAM dibidang politik lebih mengemuka yang ditandai dengan hak untuk turut dalam penyelenggaraan negara. Kemerdekaan pers merupakan suatu keharusan, sensor dan tindakan bredel dilarang. Tetapi Hatta dapat menerima pembatasaan-pembatasan yang akan diberlakukan, dan pembatasan itu hanya dapat dilakukan oleh undang-undang yang dibuat oleh oleh badan perwakilan. Hal lain yang signifikan dari pemikiran Hatta adalah hak untuk

${ }^{8}$ Moh Hatta, Ke Arah Indonesia Merdeka dalam Mariam Budiarjo, Masalah Kenegaraan, (Gramedia, Jakarta, 1980), hlm 21 
memperoleh persamaan dimuka hukum (eguality before the law). ${ }^{9}$

Puncak dari pemikiran hukum HAM dan tuntutan perjuangan hak kemerdekaan dan hak-hak lainnya mengemuka dalam pembahasan rancangan UUD di sidang BPUPKI. Data diskusi yang berlangsung dalam sidang BPUPKI ditemukan titik kesimpulan bahwa konsepsi hak asasi manusia dalam UUD merupakan hasil kompromi dari dua pemikiran, pertama, bahwa tidak tepat memasukkan nilai hak asasi manusia dalam UUD dan kelompok ini diwakili oleh Soekarno dan Supomo. Sedangkan pemikiran kedua, bahwa hak asasi manusia sudah sewajarnya dimasukkan dalam UUD dan kelompok ini diwakili oleh Moh Hatta dan Yamin.

Namun demikian, dikotomisasi tersebut masih menjadi perdebatan. Menurut penelitian Tim Unpad menyebutkan bahwa perdebatan dikotomis itu tidak sesuai dengan pembicaraan yang berlangsung pada waktu itu (BPUPKI). Data BPUPKI pada sidang tanggal, 13 Juli bahwa telah dibahas naskah UUD 1945 yang dihasilkan oleh panitia kecil yang notabene diketua oleh Supomo dan telah memuatkan pasal-pasal tentang HAM yang meliputi hak persamaan kedudukan di muka hukum, hak atas pekerjaan dan penghidupan yang layak, hak untuk memeluk agama dan kepercayaan dan lain-lain yang mencakup hak sipil dan politik. $^{10}$

Kalau pun ada perbedaan itu hanya terletak pada usul Moh Hatta agar hak berkumpul, berdialog dan mengeluarkan pikiran ditambahkan dalam ketentuan-ketentuan HAM disamping yang sudah ada dalam naskah. Mulanya Supomo berkeberatan dengan usulan Moh Hatta tersebut karena dipandang bersumber individualisme. Pemaknaan Supomo

\footnotetext{
${ }^{9}$ Bagir Manan, et. al., op. cit, hlm 21

${ }^{10}$ Tim Unpad, Konsepsi Bangsa Indonesia Tentang Hak Asasi Manusia ditinjau dari Segi Hukum, paper, 1993, hlm 4-6
} 
dipengaruhi oleh paham negara integralistik yang dikembangkannya. Namun Hatta menyangkal bahwa hak tersebut juga dikenal dalam paham kekeluargaan dan hal itu tersirat diakui oleh Supomo.

Penjelasan tersebut menegaskan kesejajaran substantif antara pemikiran Supomo-Soekarno dan Moh Hatta-Yamin yang sama-sama ditandai dengan penolakan mereka terhadap konsepsi HAM yang bersifat individualistik yang ruhnya ada dalam droit dde I'homme de du citoyen. Moh Hatta dan Yamin hanya berkeinginan memasukkan hak untuk berkumpul, berdialog dan kemerdekaan menyatakan pikiran dan bukan semua hak yang tercantum dalam droit dde I'homme de du citoyen. Karena konteks hak dalam droit de I'homme de $d u$ citoyen, menurut Moh Hatta merupakan semata mata syarat-syarat untuk mempertahankan hak-hak orang seseorang terhadap kedzaliman raja-raja dimasa dahulu. ${ }^{11}$

\section{Konstelasi Pemikiran Hukum dan HAM Orde Lama}

Awal periode rezim orde lama merupakan puncak keemasan eksistensi HAM, pemikiran-pemikiran HAM yang begitu bergejolak di era pergerakan perjuangan kemerdekaan mendapatkan legitimasi pengaturannya secara formal ke dalam UUD 1945. Instrumentasi HAM mendapatkan pengakuan secara politik dan hukum yang kemudian dijadikan fondasi bagi penyelenggaraan negara. Prinsip kedaulatan rakyat diwujudkan dalam sistem demokrasi dan negara hukum.

Demokasi berintikan kebebasan dan persamaan setiap manusia sedangkan negara hukum menjamin mikanisme dan anasir pemenuhan HAM di dalamnya. ${ }^{12}$ Kedua konsepsi

${ }^{11}$ Sekretariat Negara Ripublik Indonesia, Risalah Sidang Badan dan Panitia Persiapan kemerdekaan Indonesia (PPKI), (Jakarta, Sekretariat Negara, 1998), hlm 286-287

${ }^{12}$ Bagir Manan, Perkembangan Pemikiran... op.cit, hlm 28 
penyelenggaraan negara tersebut menjadi perantara yang sangat subur bagi tumbuh dan berkembangnya wacana dan pemikiran tentang HAM sesudahnya. Namun demikian, walaupun sudah terumuskan dengan baik dan dijamin secara konstitusional tetapi dalam perjalanannya mengalami persoalan-persoalan yang silih berganti.

Di awal kemerdekaan, karena pengaruh tuntutan merdeka teramat kuat menuju "Self Determination", pemikiran HAM mewarnai terhadap perjalanan kehidupan ketatanegaraan pada saat itu. Terutama dampak dari adanya tuduhan dari pihak Belanda beserta sekutu-sekutunya yang menilai bahwa pemerintah Indonesia yang baru berdiri sebagai pemerintah yang tidak demokratis, diktator, dan merupakan boneka dari Jepang. Untuk menangkis tuduhan tersebut, ada 3 (tiga) langkah utama yang dilakukan oleh pemerintah yang merupakan paradigma baru di bidang ketatanegaraan, yaitu : ${ }^{13}$

Pertama, mengeluarkan maklumat politik pemerintah tanggal, 1 November 1945 yang mengisyaratkan tentang tekad bangsa Indonesia yan berkeinginan untuk menegakkan yang demokratis, hubungan yang harmonis antara warga negara dengan negara, atau antara rakyat dengan rakyat dalam konteks pemikiran hak asasi manusia dan aktualisasinya dalam kehidupan bernegara.

Kedua, mengambil tindakan yang memberikan keleluasan kepada rakyat untuk mendirikan partai politik. Hal itu tampak dari maklumat pemerintah 3 November 1945 yang antara lain menyatakan bahwa pemerintah menyukai timbulnya partai-partai politik, karena dengan adanya partaipartai itulah dapat dipimpin ke jalan yang teratur segala aliran paham yang ada dalam masyarakat. Kedua, pemerintah berharap partai-partai itu telah tersusun sebelum

${ }^{13}$ Ibid, hlm 29 
dilangsungkannya pemilihan anggota badan-badan perwakilan rakyat pada bulan Januari 1946.

Maklumat 3 November 1945 sangat sarat dengan pemikiran tantang HAM dalam bidang politik, khususnya yang berkaitan dengan "right of association and togetherness". Maklumat ini juga menjadi fondasi bagi tumbuh suburnya partai-partai politik dengan berbagai macam ideologinya. Konteks ini juga menjadi awal tumbuhnya sistem multi partai di Indonesia.

Ketiga, melakukan perubahan mendasar dan signifikan terhadap sistem pemerintahan yang semula presidensil menjadi sistem pemerintahan parlementer, sebagaimana tertuang dalam maklumat pemerintah 14 November 1945, yang antara isinya disebutkan ;

"Pemerintah Ripublik Indonesia setelah mengalami ujianujian yang ketat dengan selamat, dalam tingkatan pertama dari usahanya menegakkan diri, merasa bahwa saat sekarang sudah tepat untuk menjalankan macam-macam tindakan darurat guna menyempurnakan tata usaha negara kepada susunan demokrasi. Yang terpenting dalam perubahan-perubahan susunan kabinet baru itu ialah tanggungjawab adalah di dalam tangan mentri”.

Dengan keluarnya maklumat pemerintah ini, maka anjuran pembentukan partai-partai politik berdasarkan maklumat pemerintah 3 November 1945 menjadi lebih bermakna. Bahkan, kedua maklumat pemerintah tersebut yang sama-sama meletakkan kebebasan ataupun keleluasaan, menjadi pangkal tolak tumbuh dan berkembangnya demokrasi liberal atau demokrasi parlementer.

Tepatnya pada tahun 1949, Indonesia mengalami perkembangan dan perluasan pemikiran HAM. Apalagi terkait perubahan mendasar terhadap bentuk negara Indonesia dari bentuk kesatuan menjadi bentuk negara fideral atau serikat yang bersamaan dengan terjadinya perubahan UUD 1945 menjadi konstitusi RIS tahun 1949. Konstitusi RIS 
1949 merupakan konstitusi yang sangat panjang karena terdiri dari VI Bab dan 197 pasal. $^{14}$

Pasal-pasal tentang HAM terdapat pada Bab I bagian 5 tentang Hak-hak dan Kebebasan Dasar Manusia, semuanya ada 26 pasal dengan rumusan yang sangat mendetail. Jaminan konstitusional yang lengkap dalam konstitusi RIS di Indonesia, sedikit banyak dipengaruhi oleh Universal Declaration Human Rights (UDHR) tahun 1948, dimana Majelis Umum PBB memproklamirkan pernyataan umum tentang HAM yang berisikan 30 pasal.

Sebagai negara yang baru merdeka, Indonesia membutuhkan legitimasi hak-hak yang dapat melindungi hak-hak rakyat, terutama hak yang berkaitan dengan kemerdekaan Indonesia. Indonesia menjadi anggota PBB yang ke-60 pada tahun 1950 dan otomatis terikat dengan UDHR karena PBB menegaskan bahwa keberdaan UDHR bagi setiap negara anggota $\mathrm{PBB}$ baik sendiri maupun bersama-sama wajib memajukan HAM. Negara tidak dapat mengecualikan pemenuhan HAM apalagi berlindung di balik prinsip kedaulatan atau yurisdiksi intern negara. ${ }^{15}$

Apalagi konsepsi UDHR merupakan kristalisasi pemikiran HAM pasca perang dunia II yang menyisakan pelanggaran HAM yang tidak kenal batas-batas. Pembunuhan dan kerusuhan dahsyat yang diakibatkan perang dunia II menggugah kebulatan tekad masyarakat internasional untuk melakukan upaya-upaya preventif untuk mencegah perang dengan membangun suatu organisasi internasional yang sanggup meredakan krisis internasional serta menyediakan forum untuk diskusi dan mediasi. Tekad ini berwujud dengan

${ }^{14}$ Sri Hastuti PS, Perlindungan HAM dalam Empat Konstitusi Di Indonesia, Jurnal Magister Hukum No. 1 Vol. 1 Januari 2005, Universitas Islam Indonesia, hlm 13-14

${ }^{15}$ Muh. Budairi Idjehar, HAM Versus Kapitalisme, (Insist Press, Yogyakarta,2003), hlm 84 
terbentuknya PBB, yang tujuan utamanya menjadi pelindung dan penegakan HAM di dunia internasional.

Namun demikian, sistem ketatanegaraan federal dengan konstitusi RIS tidak berlangsung lama, hanya mulai tahun 27 Desember 1949 dan berakhiir pada 17 Agustus 1950. Tetapi sistem multi partai ataupun sistem pemerintahan parlementer yang dicanangkan pada kurun waktu pertama diberlakukannya UUD 1945 masih berlanjut. Kedua sistem tersebut mendorong atas menguatnya sistem demokrasi liberal/parlementer pada tahun 1950 setelah Indonesia kembali menjadi negara kesatuan dengan berlakunya UUDS tahun 1950.

Pada periode pemberlakuan UUDS, suasana kebebasan sangat kuat, bahkan dapat dikatakan pemikiran dan aktualisasi hak asasi manusia sebagaimana konsepsi demokrasi liberal mengalami keleluasaan dan menikmati bulan madu kebebasannya, hal ini terlihat dari beberapa indikator, yaitu : ${ }^{16}$

Pertama, semakin banyak tumbuhnya partai-partai politik dengan beragam ideologinya masing-masing. Kedua, kebebasan pers sebagai salah satu pilar demokrasi betul-betul menikmati kebebasannya. Ketiga, pemilihan umum sebagai pilar demokrasi berlangsung dalam suasana kebebasan, fair dan demokratis. Keempat, parlemen atau dewan perwakilan rakyat sebagai representasi dari kedaulatan rakyat menunjukkan kinerja dan kelasnya sebagai wakil-wakil rakyat dengan melakukan kontrol/pengawasan yang semakin efektif terhadap eksekutif.

Bahkan sebegitu efektifnya, pelaksanaan fungsi pengawasan parlemen sering mengakibatkan jatuh bangunnya kabinet. Hal itu terlihat dari 7 (tujuh) buah kabinet yang muncul secara silih berganti pada periode 1950-1959, kalau dihitung berarti kurang lebih 2 (dua) tahun berganti-ganti,

${ }^{16}$ Bagir Manan, Perkembangan Pemikiran... op.cit, hlm 32 
Perihal ini tentunya sangat berpengaruh bagi stabilitas pemerintahan. Kelima, wacana dan pemikiran tentang HAM memperoleh iklim yang sangat kondusif, sejalan tumbuhnya sistem kekuasaan yang berbulan madu dengan kebebasannya.

Di tengah iklim yang seperti itu mengakibatkan perkembangan dan pemikiran HAM merasuk dan menjelajah jauh, baik dalam suasana kehidupan politik rakyat (infra struktur politik) maupun dalam suasana kehidupan politik pemerintah (supra struktur politik). Termasuk, konstituante yang diserahi kewenangan untuk menyudahi instabilitas politik pemerintahan dan diserahi membentuk UUD tetap sebagai pengganti UUDS 1950, tidak juga luput dari konstelasi wacana dan kebebasan pemikiran tentang HAM.

Perdebatan utama tentang HAM di Konstituante, sangat nampak bahwa persoalan HAM dianggap oleh semua anggota konstituante sebagai sesuatu yang sangat penting dan tidak dapat dipisahkan dari negara konstituonal. Dari perdebatan mereka terlihat bahwa HAM mendasar bagi keberadaan UUD dan tidak kalah pentingnya dari perdebatan tentang falsafah negara. Semua pembicara dalam forum konstituante bersepakat bahwa HAM perlu dikumpulkan dan dimasukkan di dalam bab khusus dalam UUD, bahkan sebagian mereka berpendapat bahwa bab tentang HAM sebaiknya mendahului bab-bab dalam UUD. ${ }^{17}$

Forum konstituante menegaskan bahwa semua golongan partai dengan pandangannya masing-masing sepakat bahwa HAM dimasukkan ke dalam bab khusus yang mempunyai sentral dalam batang tubuh UUD. Dalam perdebatan yang ada, tidak terdapat satupun pandangan yang menentang atau tidak peduli terhadap paham HAM yang universal. Namun berbeda halnya perdebatan yang terkait menyangkut masalah mendasar lainnya, semisal perihal tentang dasar negara.

${ }^{17}$ Ibid, hlm 33 
Perdebatan yang tidak kunjung usai, berlarut-larut dan tidak berhasil menyelesaikan tugasnya membuat UUD yang tetap. Kondisi itu mendorong Soekarno mengeluarkan dekrit 5 Juli 1959 yang berisi pembubaran Konstituante, menyatakan UUDS 1950 tidak berlaku, sekaligus mendeklarasikan terhadap berlakunya kembali UUD 1945 dalam penyelenggaraan pemerintahan negara. ${ }^{18}$

Pemberlakuan UUD 1945 dan penerapan demokrasi terpimpin Soekarno menghendaki penerapan suatu model demokrasi mengenai pimpinan menuju satu tujuan yaitu suatu masyarakat yang berkeadilan sosial yang harapannya memberi kebahagiaan hidup di segala lapangan, terutama sekali dilapangan ekonomi. ${ }^{19}$ Dengan konsepsi itu pula, Soekarno hendak mengaitkan demokrasi terpimpin dengan pancasila dan berbagai prinsip demokrasi.

Kurang lebih terdapat 12 (dua belas) prinsip yang dijadikan landasan demokrasi terpimpin, seperti kerakyatan yang dipimpin oleh hikmat kebijaksanaan dalam permusyawaratan/perwakilan, mengakui hak oposisi, bukan diktator, mencakup bidang politik, ekonomi, sosial dan sebagainya. ${ }^{20}$ Namun dalam prakteknya, demokrasi terpimpin lebih menampakkan suatu pemerintahan dikatatorial daripada demokrasi. Hal itu dapat dilihat dari beberapa hal, yaitu $:^{21}$

Pertama, pada tataran supra struktur politik. Dimana dengan besarnya kekuasaan yang ada di tangannya sebagai akibat diberlakukannya kembali UUD 1945 yang menganut sistem presidensiil, Presiden Soekarno melakukan retooling terhadap struktur politik dan kelembagaan untuk disesuaikan dengan sistem politik demokrasi terpimpin. Atas landasan itu, parlemen yang ada menurut UUDS 1950 dan tersusun

\footnotetext{
${ }^{18}$ Ibid, hlm 34

${ }^{19}$ Pidato Presiden Soekarno pada 17 Agustus 1957

${ }^{20}$ Usep Ranawidjaja, Hukum Tata Negara Indonesia, (Pustaka
} Star, Bandung, 1960), hlm. 62-63

${ }^{21}$ Bagir Manan, Perkembangan Pemikiran .... op. cit, hlm 36 
berdasarkan pemilihan umum 1955, diakui sebagai Dewan Perwakilan Rakyat Sementara (DPRS) sampai terbentuk Dewan Perwakilan Rakyat (DPR) baru berdasarkan UUD 1945.

Tidak lama setelah itu, Presiden Seokarno mengambil tindakan yang dinilai oleh banyak pihak sebagai inkonstituonal, setelah timbul perselisihan dengan DPRS tentang penetapan Anggaran Pendapatan dan Belanja Negara yang berakibat dibubarkannya DPR. Setelah bubar, Presiden Soekarno menyusun DPR yang baru menurut konsepsinya sendiri. DPR yang disusun Presiden Soekarno tersebut berjumlah 261 orang anggota yang separuh daripadanya berasal dari anggota-anggota partai dan separuhnya terdiri dari apa yang disebutnya sebagai golongan fungsional, yaitu buruh, tani, pemuda, wanita, alim ulama, cendikiawan, tentara dan polisi. Semua anggota yang ada ditunjuk oleh Presiden.

Dengan tindakannya itu, Presiden Soekarno bermaksud agar dalam sistem demokrasi terpimpin, DPR sebatas bertugas memberikan legitimasi terhadap keputusankeputusan yang telah ditetapkan oleh pemerintah, berdasarkan pertimbangan ataupun usul dari Dewan pertimbangan Agung (DPA) dan Dewan Perancang Nasional (DPN).

Tindakan inkonstituonal lainnya yang dilakukan Presiden dalam konteks kelembagaan (negara) adalah memberikan kedudukan menteri-menteri negara kepada semua lembaga negara, baik lembaga tertinggi negara maupun lembaga DPA, sedangkan Presiden berkedudukan sebagai ketua. Semua tindakan yang ada menegaskan bahwa tindakan dan kebijakan presiden Soekarno yang ada tidak bersesuaian dengan konstitusi UUD 1945 dan karenanya konteks itu mengisyaratkan sebagai kebijakan yang otoriter.

Kedua, pada tataran infra struktur politik. Dimana presiden Soekarno mengeluarkan Penetapan Presiden 
(Penpres) No. 7 tahun 1959 tentang syaratsyarat dan penyederhanaan kepartaian. Penpres No. 7 tahun 1959 otomatis mencabut terhadap maklumat pemerintah 3 November 1945 yang dianggap sebagai penyebab maraknya partai politik serta timbulnya instabilitas politik dan pemerintahan. Setelah itu, Presiden Soekarno mengeluarkan Peraturan Presiden No. 13 tahun 1960 tentang pengakuan, pengawasan dan pembubaran partai-partai.

Peraturan-peraturanan tersebut memberikan kekuasaan mutlak kepada Presiden Soekarno untuk meredam suara dan melenyapkan kekuatan-kekuatan (partai) politik yang dipandang menghalang-halangi kebijaksanaan politiknya. Hal itu terbukti dengan dibubarkannya partai Masyumi, Partai Sosialis Indonesia (PSI) dan Partai Murba. Dua partai pertama, Masyumi dan PSI dibubarkan dengan tuduhan ikut terlibat dalam pemberontakan PRRI/Permesta. Sedangkan partai-partai lainnya diakui tetapi mendapatkan pengawasan yang sangat kuat.

Selain kebijakan kontroversial di atas, tindakan diktatorial Presiden Soekarno dalam menjalankan kerja-kerja demokrasi terpimpin ialah langkah represif yang dilakukannya terhadap pers, terutatama media massa cetak. Dibandingkan dengan banyaknya media massa cetak pada kurun waktu 1959-1966 sebanyak 65 dengan tindakan pemerintah sebanyak lebih dari 35 kali, maka itu berarti setiap tahun dilakukan tindakan terhadap satu dari dua media massa cetak.

Dalam perspektif sistem politik demokrasi terpimpin dapat disimpulkan bahwa supra struktur dan infra struktur politik di bawah kendali kekuasaan refresif Soekarno. Dalam perspektif pemikiran tentang HAM, terutama hak sipil dan politik, sistem politik demokrasi terpimpin tidak memberikan keleluasaan ataupun kekuasaan adanya kebebasan (berserikat, berkumpul, dan mengeluarkan pikiran dan tulisan). 
Demokrasi terpimpin dapat dikatakan menjadi salah satu penghambat, pembatasan dan memundurkan terhadap perkembangan pemikiran tentang HAM, hal ini berbeda sama sekali dengan kondisi pada pada era demokrasi liberal/parlementer. Gugatan sosial masyarakat dari berbagai kalangan, mulai mahasiswa, tokoh intelektual, korban kebijakan diskriminatif dan para pekerja pers menguat sedemikian rupa dan secara tidak langsung mendorong pada kejatuhan Soekarno dari kursi kepemimpinannya.

\section{Konstelasi Pemikiran Hukum dan HAM Orde Baru}

Kelahiran orde baru diawali oleh pemberontakan G30S/PKI pada tanggal, 30 September 1966 yang mengakibatkan terhadap terbunuhnya beberapa perwira tinggi TNI yang diikuti dengan situasi chaos yang terjadi di hampir seluruh wilayah Indonesia. Kondisi ini mengantarkan Indonesia pada masa-masa sulit, kelam, gelap dan hidup dalam era yang tidak menentu arahnya. Puncaknya, Presiden Seokarno mengeluarkan Surat Perintah 11 Maret (Super Semar) tahun 1966 yang dijadikan landasan Soeharto untuk mengamankan Indonesia.

Berbekal Super Semar dan pemerintahan Soekarno yang dianggap gagal oleh MPRS, Soeharto akhirnya terpilih menggantikan Soekarno. Soeharto meroket karena posisinya yang dianggap pahlawan melakukan penumpasan terhadap pemberontakan G30S/PKI dan mengganggu terhadap stabilitas negara bahkan akan menghancurkan ideologi negara. Pergantian kepemimpinan di saat itu dibarengi dengan harapan yang teramat kuat terhadap kembalinya supremasi hukum dan penghormatan terhadap HAM.

Pada tahun 1967 berlangsung seminar tentang HAM, gagasan tentang pengadilan HAM mulai dikemukakan. Selanjutnya berbagai seminar diadakan oleh kalangan masyarakat, antara lain seminar tentang Hukum II tahun 1968 yang mengukuhkan harapan besar dan membuat 
rekomendasi-rekomendasi penting. Salah satu wujud rekomendasi tersebut ialah perluanya praktek hak uji materil (judicial review) untuk dilakukan guna melindungi HAM itu sendiri. ${ }^{22}$

Harapan yang teramat besar terhadap Soeharto tersebut tidak kunjung terwujud. Era-era setelah tahun 1970-an masyarakat Indonesia kembali dihadapkan dengan kondisikondisi yang sama sekali tidak menghargai terhadap HAM, dalam taraf kebijakan muncul kebijakan tentang Fusi Partai Politik, SIUP, NKK/BKK, UU Asas Tunggal Pancasila, Kebijakan hubungan industrial Pancasila (HIP) bagi pekerja, dan lainnya. Sedangkan level praktek terjadi berbagai pelanggaran HAM di banyak tempat, mulai Komando Jihad, Usroh, Tanjung Priok, Petrus, DOM Aceh, Talangsari, dan lain sebagainya.

Di era orde baru, pemikiran tentang HAM dianggap sebagai pemikiran barat dan bersifat individualis dan berbeda dengan konsepsi HAM Pancasila. Pemerintah di sini yang lain mengembangkan pemikiran tentang pembangunan ekonomi, sehingga slogan yang kerapkali muncul oleh pemerintah ialah "pembangunan ekonomi" dan segala tindakan yang yang bernada kritis terhadap pemerintah dituduh mereka sebagai tindakan penentangan terahadap tujuan pembangunan sehingga harus dihancurkan.

Di era orde baru, penghormatan dan penegakan HAM tidak berkembang sama sekali bahkan mundur total. Konvensi HAM hanya tiga yang diratifikasi yaitu Konvensi Penghapusan Segala Bentuk Diskriminasi Terhadap Perempuan (UU No. 7/1984), Konvensi Internasional Menentang Apartheid dalam olahraga (Keppres No. 48/1993) dan Konvensi Hak Anak (Keppres No. 36/1990), sedangkan di sisi yang lain muncul berbagai aturan dan kebijakan yang sangat anti terhadap HAM.

${ }^{22}$ Ibid, hlm 41 
Secara umum, konfigurasi politik rezim orde baru ialah, pertama, negara menjelma menjadi kekuasaan teror (state terorisme), dimana negara secara sistemik melakukan penundukan secara paksa dan represif yang bersifat fisik (state sponsored). ${ }^{23}$ Diantara kasus kekerasan yang dilakukan oleh orde baru ialah, kasus Waduk Kedungombo, Nipah, pembredelan terhadap majalah semisal majalah Tempo, majalah Abadi, majalah Indonesia Raya, dan majalah Pedoman, kasus DOM di Aceh, kasus Tanjung Priok, kasus Trisakti, kasus Timor Timur, Tragedi 27 Juli 1996 di Kantor DPP PDI di Jalan Deponegoro, Tragedi Makasar Berdarah dan masih lainnya.

Pada level kekerasan kebijakan muncul aturan dan kebijakan seperti, kebijakan NKK (SK 028/1878 Menteri P dan K dan diperbaiki dengan SK. P dan K No. 0156/U/1978 yang disertai perangkat BKK-nya), Pembekuan kegiatan mahasiswa (Skep 02/Kopkam/1978 Komkamtib), UU. No 8/1985 tentang Asas Tunggal, aturan Subversi, peraturan SIUP, Instruksi Presiden No. 14 Tahun 1967 tentang Agama, Kepercayaan dan Adat istiadat Cina, Kep. Presidium No. 127/U/Kep/12/1966 mengenai Peraturan Ganti Nama Bagi WNI Memakai Nama Cina, Keppres No. 57 tahun 1995 tentang tata cara Penyelesaian Permohonan Pewarganegaraan Republik Indonesia, UU No. 11/PNPS/1963 tentang menentang pemerintah dan dasar negara pancasila, dan banyak lagi lainnya.

Kedua, upaya penundukan rezim orde baru juga dilakukan dengan strategi state corporatisme. Dimana dalam konteks ini negara tidak hanya melakukan penundukan dengan kekerasan (represif) tetapi juga negara menciptakan jejaring institusi yang tujuannya memperkuat dan mengokohkan peran negara dalam melakukan kerja-kerja

23 Pratikno, Keretakan Otoriterisme Orde Baru dan Prospek Demokratisasi, Jurnal Ilmu Sosial Politik, Fisipol UGM, Yogyakarta, Vol. 2 No. 2 November 1998 
kebijakannya. Pada tingkat nasional korporatisme negara terwujud dengan keberadaan organisasi PWI, SPSI MUI, KNPI, IDI KORPRI, PGI, KWI, PHDI dan lain sebagainya. Pada tingkat lokal muncul organisasi korporatisme negara semisal Karang Taruna, Pendidikan Kesejahteraan Keluarga (PKK), Kelompok Pendengar, Pembaca dan Pemirsa (Kolampencapir), dan Lainnya. ${ }^{24}$

Ketiga, negara melakukan strategi state clientilisme, dimana berusaha melakukan penundukan kepada pasar. Hal ini diwujudkan dengan upaya negara untuk mendominasi kehidupan perekonomian yang menghasilkan kebijaksanaankebijaksanaan proteksi, subsidi dan lainnya. Dominasi negara dalam perekonomian pada perkembangannya juga menghasilkan pola hubungan patron client, dimana negara tidak jarang bertindak sebagai patron, sedangkan pengusaha-pengusaha tertentu yang dekat dengan kekuasaan bertindak sebagai client-nya.

Pola-pola hubungan yang dibangun Soeharto akhirnya menimbulkan sistemiknya kasus Korupsi, Kolusi, dan Nepotisme (KKN) tetapi tidak pernah tersentuh akibat posisi negara yang juga telah menjelma state terorisme. ${ }^{25}$ Kasus nyata partner Soeharto semisal Bob Hasan, Sudono Salim (Liem Siolong), Tutut dan masih banyak lainnya, sedangkan di level internasional muncul pengusahapengusaha seperti CGI, IBRD, investor AS, investor Taiwan, investor Hongkong dan masih banyak lainnya.

Keempat, rezim orde baru mengokohkan kekuasaannya juga dengan rekayasa dan strategi penguasaan opini publik. Negara dalam konteks ini biasa disebut sebagai state discourse, dimana negara melakukan hegemoni melalui

24 Cornelis Lay dan Pratikno, Komnas HAM 1998-2001 : Pergulatan dalam Transisi Politik, Fisipol UGM, Yogyakarta, 2002, hlm 34, lihat juga Muhammad AS Hikam, Demokrasi an Civil Society, (Pustaka LP3ES Indonesia, Jakarta), 1999,hlm 121

${ }^{25}$ Ibid 
instrumen mobilisasi opini dan sikap publik. ${ }^{26}$ Hal terlihat dari penggunaan istilah demokrasi Pancasila, cap ekstrim kanan dan kiri, anti Pancasila, anti pembangunan, pemberlakuan program penataran P4 dan bahkan kebijakan P4 ini dijadikan alasan administratif semisal mau keluar negeri, daftar PNS dan sebagainya.

Konfigurasi politik rezim orde baru di atas akhirnya menampakkan wajahnya sebagai rezim otoritarian, pelanggar HAM dan membangun sistem kenegaraan sebagai tata kelola keluarga dan clientist. Secara umum pemikiran dan pemenuhan HAM di era rezim orde baru macet total dan bahkan terjadi politisasi HAM dengan mengatasnamakan relatifisme kultural pancasila. Orde baru berlindung atas nama HAM pancasila dibalik pelanggaran-pelanggaran HAM yang sistemik yang dilakukannya dan menutup gugatan publik atas KKN yang telah dilakukannya secara clientist.

\section{Desakan Masyarakat Internasional terhadap Rezim Orba}

Satu hal yang mendapat perhatian masyarakat global ialah hiruk pikuk politik, kekerasan, dan dibungkamnya HAM di Indonesia. Diskursus itu menggumpal dan melahirkan solidaritas bersama di tingkatan masyarakat global, hal ini yang biasa kita kenal dengan solidaritas masyarakat sipil internasional untuk sama-sama bersatu melawan ketidakadilan dan kekerasan yang dilakukan oleh negara. $^{27}$

Secara politik, masyarakat internasional berkepentingan pada perluasan demokrasi, dan dalam rangka itu mendesak setiap negara yang belum demokratis untuk melakukan

${ }^{26}$ Ibid, juga lihat Zainuddin Maliki, Politikus Busuk : Fenomena Insenbilitas Moral Elite Politik, (Galang Press, Yogyakarta), 2004, hlm 224-225

27 Andi Widjajanto, dkk,Transnasionalisasi Masyarakat Sipil, (LkiS, Yogyakarta, 2007), hlm 37 
penyesuaian diri. Pada saatnya kelak, dunia pun akan diisi oleh sistem politik dan masyarakat demokratis sehingga "sejarah pun berakhir". ${ }^{28}$ Perubahan sikap orde baru atas desakan demokrasi dan penghormatan HAM memang menjadi niscaya karena konfigurasi dunia berada pada kondisi konstelasi yang mulai menunjukkan titik akhir kehancuran komunisme dan munculnya dominasi barat. ${ }^{29}$

Terkait tekanan internasional, BJ Habibie yang menggantikan jabatan Soeharto mengaku bahwa dirinya telah dihubungi dan menerima masukan dari para pemimpin dunia terkait persoalan-persoalan di Indonesia utamanya kasus pelanggaran HAM berat yang terjadi di Timur-Timor, Sekjen PBB Kofi Annan, Perdana Menteri Inggris Tony Blair, Presiden Nelson Mandela dari Afrika Selatan dan bahkan sempat bertemu dan disurati oleh PM Australia John Howard, serta desakan komunitas pejuang hak asasi manusia di dunia internasional.

Sehingga BJ. Habibe berkesimpulan dan mengambil kebijakan, pertama, Timor-Timur bukanlah koloni Indonesia dan alasan MPR pada tahun 1978 untuk menerima TimorTimur karena alasan persamaan nasib. Kedua, penyelesaian masalah di PBB mengenai Timor-Timur yang berkepanjangan dapat menghambat jalannya reformasi. Ketiga, masalah Timor-Timur sudah harus diselesaikan sebelum Presiden ke-4 Republik Indonesia dipilih sehingga yang bersangkutan dapat mencurahkan perhatian kepada

${ }^{28}$ Eep Saefullah Fatah, Catatan atas Gagalnya Politik Orde Baru, Pustaka Pelajar, Yogyakarta, 1998, hlm xxxiv-xxxv dengan mengutip pendapatnya Francis Fukuyama dalam "The End of History and The Last Man, Hamish Hamilton, London, 1992

${ }^{29}$ Firdaus, Imlikasi Pengaturan HAM dalam UUD terhadap Ius Constitiendum, dalam Muladi (edit), Hak Asasi Manusia, Politik dan Sistem Peradilan Pidana, Undip, Semarang, 2007, hlm 11 
penyelesaian masalah nasional dan reformasi yang sedang Indonesia hadapi.$^{30}$

Secara umum desakan komunitas internasional dengan berbagai metode dan jejaringnya di dunia global sangat mempengaruhi terhadap konstelasi sosial politik masyarakat di Indonesia dan juga sangat mempengaruhi terhadap perubahan-perubahan kebijakan rezim orde baru dan bahkan pelepasan Timor-Timur dari wilayah Negara Kesatuan Republik Indonesia (NKRI) di Era BJ. Habibie.

Beberapa contoh desakan itu ialah kutukan dunia internasional terhadap pelanggaran HAM berat TimorTimur, pelanggaran HAM di Irian Jaya, DOM di Aceh, kasus Tanjung Priuk, kasus TSS, pembentukan Komisi Nasional HAM tahun 1993, tuntutan pembentukan pengadilan HAM Ad Hoc untuk pelanggaran HAM berat masa lalu, serta masih banyak lainnya. Situasi tuntutan masyarakat internasional secara tidak langsung merupakan respon atas kegelisahan dan berbagai tuntutan masyarakat nasional yang sudah memuncak karena secara sistemik dilanggar hak-haknya oleh rezim orde baru.

\section{Konfigurasi Politik dan Hukum Pasca Jatuhnya Rezim Orde Baru}

Jatuhnya rezim otoritarian orde baru pada 21 Mei 1998 secara tidak langsung merupakan akibat dari gelombang desakan masyarakat nasional dan internasional. Tetapi secara ril kejatuhan Soeharto ialah akibat dari krisis moneter yang sangat sistemik menimpa keuangan nasional sebagai akibat krisis moneter yang menimpa negara Asia lainnya. Huru-hara politik dan sosial nasional menyebabkan pemerintahan tidak berdaya sama sekali.

Gelombang gugatan masyarakat dan krisis moneter yang ada menentukan wajah konfigurasi politik dan hukum pasca

${ }^{30}$ Baharuddin Jusuf Habibie, Detik-Detik yang Menentukan, Jalan Panjang Indonesia Menuju Demokrasi, (THC Mandiri, Jakarta, 2006), hlm 237 
jatuhnya rezim orde baru. Dalam konteks politik, perubahan ditandai dengan terjadinya liberalisasi politik yang sekaligus menjadi awal bagi datangnya transisi menuju demokrasi Indonesia. Walaupun sangat dipahami bahwa liberalisasi politik yang ada belum tentu mengarah pada demokrasi, namun yang penting ialah bahwa ketika perubahan itu digulirkan maka berbagai aktor politik akan muncul dan melibatkan diri dalam proses interaksi antar kekuatan politik. $^{31}$

Liberalisasi politik ini sangat terlihat dari berbagai kebijakan yang yang diambil oleh pemerintahan BJ.Habibie, semisal kebijakan pelonggaran media massa dalam pemberitaannya, kebebasan dalam pendirian partai politik, pengakuan perbedaan pendapat dan demonstrasi, pencabutan peraturan tentang subversi, pembebasan tahanan politik dan kebijakan-kebijakan lainnya yang bersesuaian dengan aspirasi politik pasca otoritarian.

Pada perkembangannya, liberalisasi politik ini berpengaruh pada banyak hal diantaranya, pertama, sistem kepartaian barubah dengan ditandainya dengan lahirnya partai-partai politik peserta pemilu. Dimana tidak kurang dari 150 partai politik yang lahir dan berharap mengikuti pemilu pada tahun 1999, namun setelah seleksi dilakukan oleh KPU akhirnya yang ditetapkan hanya 48 partai politik. Hal ini berbeda sama sekali dengan pemilu sebelumnya yang hanya diikuti oleh 3 partai politik yaitu Golkar, PPP dan PDI.

Kedua, liberalisasi politik juga ditandai dengan bermunculannya berbagai aliran ideologi semisal Islam, nasionalisme, sosialisme, konfusionisme dan lain sebagainya dengan berbagai variannya. Hal ini berbeda sama sekali di waktu rezim orde baru yang hanya membolehkan ideologi

${ }^{31}$ Guillermo O’Donnel dan Philippe C. Shimitter (ed), Transisi Menuju Demokrasi, Rangkaian Kemungkinan dan Ketidakpastian, Jakarta, LP3ES, 1993, dalam Cornelis dan Pratikno, Komans HAM...op.cit., hlm 36 
pancasila sebagai asas politik dan seluruh lembaga karena alasan stabilitas dan pembangunan, yang karenanya menyebabkan diskriminasi terhadap hak asasi manusia yang sangat sistemik.

Ketiga, terjadinya pergeseran relasi kekuasaan diantara lembaga kekuasaan dan lembaga pemerintahan baik ditingkat lokal maupun di tingkat nasional. Hal ini terjadi ketika penguatan peranan partai politik pada perkembagannya juga berlanjut kepada penguatan lembaga perwakilan rakyat. Dominasi lembaga perwakilan rakyat, MPR, DPR dan DPRD, dalam proses pemerintahan menjadi sangat menonjol. Tidak jarang terjadi friksi yang sangat tajam diantara lembaga legislatif dengan lembaga eksekutif. ${ }^{32}$

Contoh yang masih segar diingatan kita ialah pemberhentian Abdurrahman Wahid sebagai Presiden dengan alasan Bullogate dan Bruneigate yang ternyata tidak terbukti dan akal-akalan, dan pada tingkatan lokal sebagaimana di Kabupaten Sampang dan Buleleng, DPRD mampu menuntut dan memutuskan pemberhentian atau pengangkatan kepala daerah setempat. Hal ini sangat berbeda dengan rezim orde, yang lembaga perwakilannya mengutip lagu Iwan Fals hanyalah menjadi "lembaga paduan suara yang sekedar menyanyikan lagu setuju" atas titah eksekutif.

Keempat, sistem pemerintahan yang sebelumnya sentralistik maka setelah kejatuhan rezim orde baru menjadi desentralisasi. Bahkan pilihan sistem desentralisasi ini merupakan jawaban satu-satunya atas menguatnya diskursus disintegrasi bangsa akibat kelaliman pemerintah pusat terhadap pemerintah daerah di era orde baru.

Ironisme rezim orde baru yang sentralistik dan otoriter diakui oleh BJ. Habibie dan termasuk rencana langkahlangkah kebijakannya sebagai presiden pertama di era

${ }^{32}$ Ibid, hlm 38 
reformasi, yaitu, ${ }^{33}$ pertama, dirinya mewarisi bentuk institusi kepresidenan yang sangat berkuasa dalam lingkungan dan budaya feodal sehingga ia harus akhiri. Kedua, para tahanan politik harus dilepaskan, tidak boleh lagi terjadi bahwa yang bertentangan dengan pendapat atau rencana Presiden harus dimasukkan ke penjara kecuali mereka yang terbukti telah melaksanakan tindakan kriminal.

Ketiga, kebebasan berbicara, kebebasan mengeluarkan pendapat, kebebasan pers, dan kebebasan berunjukrasa harus segera dilaksanakan. Keempat, DPR dan MPR harus diberi legitimasi yang kuat berdasarkan pemilu yang demokratis serta kesempatan untuk mendirikan partai politik apa saja, asalkan diperbolehkan dan tidak melanggar UUD 1945 dan ketetapan MPR. Kelima, sidang istimewa MPR harus segera diselenggarakan dalam waktu sesingkat-singkatnya untuk memberi dasar hukum bagi reformasi dan pemilu yang dibutuhkan.Namun demikian, harus diakui bahwa liberalisasi kebijakan politik BJ.Habibie adalah kepastian dan merupakan keniscayaan, hal ini didasari oleh fakta-fakta sosiologis bahwa telah terjadi pemberontakan dan perlawanan dari rakyat yang sangat massif terhadap otoriterisme orde baru. Kumandang tuntutan reformasi total dan iring-iringan demonstrasi yang meneriakkan perubahan revolusi terjadi dimana-mana di wilayah nasional.

Bahkan, desakan yang sangat kuat juga datang dari komunitas internasional yang mendesak Indonesia untuk menyelesaikan kasus pelanggaran HAM yang terjadi di Timur-Timor dan Papua. Sehingga dalam konteks ini, liberalisasi politik dan kebijakan pasca jatuhnya rezim orde baru adalah satu hal yang tidak bisa dihindari oleh pemerintah, dan sangat tidak mungkin pemerintahan baru akan mengambil politik otoritarian karena situasi gejolak

\footnotetext{
${ }^{33}$ Baharuddin Jusuf Habibie, Detik-Detik ...... op.cit., hlm 57-58
} 
sosial nasional dan berbagai desakan dunia internasional yang kuat.

\section{E. Instrumentasi Hukum HAM Pasca Reformasi}

Liberalisasi kebijakan politik pasca jatuhnya rezim orde baru berpengaruh besar juga pada instrumentasi HAM pasca reformasi. Turunnya Seoharto sebagai simbol rezim tiran membawa dampak yang sangat penting bagi pemajuan dan perlindungan hukum dan HAM. Pengkajian ulang dan instrumentasi produk hukum baru yang berkaitan dengan HAM mulai dilakukan dengan progresif dan responsif.

Demikian pula adopsi instrumen-instrumen HAM internasional ditingkatkan. Hasilnya, banyak norma-norma hukum HAM internasional yang diratifikasi kedalam peraturan perundangan-undangan nasional. Masa ini tampaknya menandai era diterimanya konsep universalisme HAM. ${ }^{34}$ Dalam konteks ini telah disusun berbagai instrumen hukum terkait hukum HAM termasuk telah dibentuk beberapa lembaga yang menangani terhadap persoalanpersoalan yang berkaitan dengan perlindungan, penghormatan dan pemenuhan HAM.

Periode pasca reformasi, bisa dikatakan sebagai tahapan penentuan dan penataan aturan secara konsisten yang bersesuaian dengan prinsip-prinsip HAM universal. Pada periode ini ditandai dengan tumbuhnya pemahaman dan kesadaran semua elemen masyarakat bahwa eksistensi HAM merupakan hak dasar yang melekat pada setiap manusia tanpa diskriminasi, yang keberadaanya harus dihormati, dijunjung tinggi dan dipenuhi.

Di antara instrumentasi hukum HAM yang terproduksi pasca reformasi adalah TAP MPR No. XVII/MPR/1998

${ }^{34}$ Artidjo Alkostar, Pengadilan HAM, Indonesia dan Peradaban, (PUSHAM UII, Yogyakarta, 2004), hlm 54 
tentang HAM, ${ }^{35}$ UUD 1945 setelah amandemen, UU. No. 39 tahun 1999 tentang HAM, UU No. 26 tahun 2000 tentang Pengadilan HAM, UU No. 35 Tahun 2014 tentang Perubahan atas UU No. 23 tahun 2002 tentang Perlindungan Anak, UU No. 20 tahun 2003 tentang Sistem Pendidikan Nasional, UU No. 23 tahun 2004 tentang Penghapusan Kekerasan Dalam Rumah Tangga, UU No. 13 tahun 2006 tentang Perlindungan Saksi dan Korban, UU No. 40 tahun 2008 tentang Penghapusan Diskriminasi Ras dan Etnis, UU No. 14 tahun 2008 tentang Keterbukaan Informasi Publik, UU No. 25 tahun 2009 tentang Pelayanan Publik, UU No. 8 Tahun 2016 tentang Hak Penyandang Disabilitas dan beberapa regulasi hukum terkait lainnya.

Selain berbagai instrumen Undang-Undang di atas, pemerintah pasca reformasi juga telah meratifikasi kovenan dan konvensi internasional yang berarti bahwa pemerintah Indonesia telah menyatakan kesediaannya untuk diikat oleh suatu perjanjian yang bersifat internasional, Beberapa instrument internasional yang telah diratifikasi dan diaksesi adalah Konvensi Iinternasional tentang Penghapusan Segala Bentuk Rasial (25 Juni 1999/aksesi), Kovenan Hak Sipil dan Politik (23 Februari 2006/aksesi), Kovenan Hak Ekonomi, Sosial dan Budaya (23 Februari 2006/aksesi), Konvensi Penghapusan Segala Bentuk Diskriminasi Terhadap Perempuan (13 September 1984), Konvensi Menentang Penyiksaan dan Perlakuan atau Hukuman Lainnya yang Kejam, Tidak Manusiawi atau Merendahkan Martabat Manusia (28 Oktober 1998), Konvensi tentang Hak Anak (5 September 1990), Konvensi tentang Perlindungan Hak-hak

35 Terkait hal ini, BJ. Habibie membuat Rencana Aksi Nasional HAM (RAN-HAM) tahun 1998-2003, yang memuat agenda pemerintahannya dalam penegakan HAM, meliputi pendidikan dan sosialisasi HAM serta program ratifikasi instrumen internasional HAM. lihat, Suparman Marzuki, Politik Hukum Hak Asasi Manusia Di Indonesia, Bahan Bacaan Mata Kuliah HAM, Program Magister Ilmu Hukum UII tahun 2010, tanpa halaman 
Pekerja Migran dan Anggota Keluarga (31 Mei 2012), Konvensi Internasional untuk Perlindungan Semua Orang dari Penghilangan Paksa (27 September 2010/aksesi), dan Konvensi tentang Hak-hak Penyandang Disabilitas (13 November 2011).

Dari berbagai instrumen yang berkaitan dengan perlindungan dan pemenuhan HAM di atas, dapatlah dikatakan bahwa pemerintahan pasca reformasi telah responsif dan progresif untuk melakukan instrumentasi terkait perlindungan, penghormatan dan pemenuhan HAM. Walau pun demikian, ada catatan-catatan penting, setidaknya dua hal, Pertama, respon dan progresifitas pemerintah terhadap instrumentasi hukum HAM di atas, belum sepenuhnya menjamin perlindungan dan pemenuhan HAM. Bila dikritisi, beberapa norma hukum HAM dibuat tapi pada sisi yang lain sulit untuk dipenuhi karena pertanggungjawaban dan mekanisme penyelesaian pelanggaran yang lemah.

Kedua, lemahnya substansi material hukum HAM pasca reformasi berdampak pada buruknya pemenuhan dan penegakan HAM secara praksis. Contoh produk hukum HAM pasca reformasi yang bermasalah ialah UU No. 26 tahun 2000 tentang Pengadilan HAM. Undang-Undang ini terbilang responsif karena dipersiapkan untuk menyelesaikan kasus-kasus pelanggaran berat HAM atau kejahatan sangat serius (the most serious crime) masa lalu. Masalahnya Undang-Undang ini sengaja dbuat lemah, hukum acara menggunakan standar biasa (KUHAP), agresi dan perang tidak dimasukkan dalam Undang-Undang dan dalam prakteknya, kasus yang telah diproses lewat pintu pengadilan semuanya gagal. $^{36}$

36 Suparman Marzuki, Politik Hukum Hak Asasi Manusia di Indonesia di Era Reformasi (Studi Tentang Penegakan Hukum HAM dalam Penyelesaian Pelanggaran HAM Masa Lalu), Ringkasan Disertasi 


\section{F. Kesimpulan}

Berangkat dari uraian di atas dapat disimpulkan bahwa konstelasi pemikiran hukum HAM historis dan fakta-fakta sosioligis yang menyertainya sangatlah mempengaruhi terhadap instrumentasi hukum HAM pasca reformasi. Hal ini bisa dilihat dari fakta-fakta historis dan sosiologis bahwa keberadaan pemikiran HAM dan kemudian dilanjutkan dengan instrumentasi hukum HAM sesudahnya tidak bisa dilepaskan dari konstelasi sosial dan berbagai pelanggaran HAM yang menyertainya.

Pemikiran HAM yang digagas oleh kaum pelajar dan rakyat sebelum kemerdekaan Indonesia, diawali oleh situasi dan kondisi penjajahan yang menyesengsarakan. Kaum pribumi yang didiskriminasi dan mendapatkan penindasan dari pemerintah kolonial mendorong pelajar untuk berserikat dan meneriakkan perlawanan terhadap penjajahan. Keberadaan organisasi Boedi Oetomo, Perhimpunan Indonesia, Sarekat Islam, Indische Partij, PNI dan perkumpulan lainnya ialah semata ingin mengangkat hak-hak kaum pribumi yang tertindas dan mendesakkan pemenuhan hak untuk mendapatkan kemerdekaan (the right of self determination). Pemikiran HAM para pemuda dan rakyat itu kemudian berpuncak pada persiapan kemerdekaan yang landasannya konstitusionalnya dibahas oleh BPUPKI.

Di Era orde lama, pemikiran tentang HAM berkembang cukup responsif dan progresif. Bahkan di periode ini, kebijakan tentang HAM menjadi senjata pemerintahan untuk melawan opini yang dikembangkan pemerintahan Belanda dan sekutunya bahwa rezim orde lama adalah pemerintahan yang otoritarian, tidak demokratis dan menjadi boneka Jepang. Rezim orde lama menjadi masa-masa indah penghargaan dan penghormatan terhadap HAM yang secara

Program Doktor Ilmu Hukum Program Pasca Sarjana Fakultas Hukum UII, 2010 
hukum HAM bisa dibaca dalam UUD RIS, UUDS, perdebatan dalam sidang konstituante dan kebijakankebijakan lainnya. Penghargaan terhadap HAM di era ini menjadi macet setelah Soekarno mengeluarkan dekrit 5 Juli 1959 yang berisi pembubaran Konstituante, menyatakan UUDS 1950 tidak berlaku dan menerapkan demokrasi terpimpin. Pasca itu, rezim orde lama berubah menjadi pemerintahan yang otoriter.

Rezim orde baru yang menggantikan rezim orde lama, juga melanjutkan kekuasaan yang otoritarian. Pemikiran HAM dalam periode ini mengalami kemacetan total dan terjadi politisasi terhadap pemaknaan HAM yang dituduh individualis dan bertentangan dengan HAM pancasila. Orde baru berlindung dibalik HAM pancasila untuk menutupi berbagai pelanggaran HAM yang sistemik, berbagai praktek KKN dan kebijakan-kebijakannya yang sangat diskriminatif. Perlindungan dan Pemenuhan di era orde baru lebih buruk dibandingkan dengan demokrasi terpimpin rezim orde lama. Rezim orde baru akhirnya didesak turun oleh masyarakat nasional yang massif dan disudutkan dalam pergaulan dunia internasional karena berbagai pelanggaran HAM yang dilakukannya.

Pasca jatuhnya rezim orde baru dengan beban berbagai pelanggaran HAM, KKN dan sistem politiknya yang diskriminatif mendorong konfigurasi politik yang liberal dan menjadi penanda dari transisi menuju demokrasi pasca reformasi. Liberalisasi politik ini sangat terlihat dari berbagai kebijakan pemerintahan BJ. Habibie seperti kebijakan pembebasan media massa dalam pemberitaannya, pembebasan pendirian partai politik dengan berbagai macam ideologinya, pengakuan perbedaan pendapat, pencabutan aturan subversi, pembebasan tahanan politik dan kebijakankebijakan lainnya yang berbeda sama sekali dengan nuansa kebijakan rezim otoritarian. 
Liberalisasi politik pasca orde baru mendorong instrumentasi hukum HAM diawali dengan munculnya TAP MPR No. XVII/MPR/1998 tentang HAM yang isinya seperti Piagam HAM. Ketenuan ini memerintahkan lembagalembaga tinggi negara untuk memajukan perlindungan HAM dan melakukan ratifikasi terhadap kovenan dan konvensi internasional tentang HAM. Pasca Ketetapan MPR tersebut muncul berbagai aturan nasional yang berkaitan dengan HAM dan meratifikasi beberapa konvensi internasional tentang HAM. Ketentuan-ketentuan tersebut dengan berbagai kelemahannya menjadi landasan perlindungan, penghormatan, dan pemenuhan HAM sampai saat ini.

\section{Daftar Pustaka}

\section{Buku :}

Bagir Manan, 2001, Perkembangan Pemikiran dan Pengaturan HAM di Indonesia, Yayasan Hak Asasi Manusia, Demokrasi dan Supremasi Hukum, Bandung Sartono Kartodirjo, (et.al), 1975, Sejarah Nasional Indonesia

$V$, Departemen Pendidikan dan Kebudayaan, Jakarta

Wangsa I Wijaya, 1988, Mengenang Bung Hatta, CV Haji Masaagung, Jakarta

Moh. Hatta, 1980, Ke Arah Indonesia Merdeka dalam Mariam Budiarjo, Masalah Kenegaraan, Gramedia, Jakarta

Tim Unpad, 1993, Konsepsi Bangsa Indonesia Tentang Hak Asasi Manusia ditinjau dari Segi Hukum, paper

Sekretariat Negara Ripublik Indonesia, 1998, Risalah Sidang

Badan dan Panitia Persiapan kemerdekaan Indonesia (PPKI), Jakarta, Sekretariat Negara

Muh. Budairi Idjehar, 2003, HAM Versus Kapitalisme, Insist Press, Yogyakarta 
Ranawidjaja, 1960, Hukum Tata Negara Indonesia, Pustaka Star, Bandung

Cornelis Lay dan Pratikno, 2002, Komnas HAM 1998-2001 : Pergulatan dalam Transisi Politik, Fisipol UGM, Yogyakarta

Muhammad AS Hikam, 1999, Demokrasi an Civil Society, Pustaka LP3ES Indonesia, Jakarta

Zainuddin Maliki, 2004, Politikus Busuk : Fenomena Insenbilitas Moral Elite Politik, Galang Press, Yogyakarta

Eep Saefullah Fatah, 1998, Catatan atas Gagalnya Politik

Orde Baru, Pustaka Pelajar, Yogyakarta

Muladi (edit), 2007, Hak Asasi Manusia, Politik dan Sistem

Peradilan Pidana, Undip, Semarang

Baharuddin Jusuf Habibie, 2006, Detik-Detik yang Menentukan, Jalan Panjang Indonesia Menuju

Demokrasi, THC Mandiri, Jakarta

Artidjo Alkostar, 2004, Pengadilan HAM, Indonesia dan Peradaban, PUSHAM UII, Yogyakarta

Suparman Marzuki, 2010, Politik Hukum Hak Asasi Manusia di Indonesia di Era Reformasi (Studi Tentang Penegakan Hukum HAM dalam Penyelesaian Pelanggaran HAM Masa Lalu), Ringkasan Disertasi

Program Doktor Ilmu Hukum Program Pasca Sarjana Fakultas Hukum UII

Manfred Nowak, 2003, Pengantar Pada Rezim HAM Internasional (Terjemahan), Pustaka Hak Asasi

Manusia Raoul Wallenberg Institute, tanpa tempat

Rhona K.M Smith dkk, 2008, Hukum Hak Asasi Manusia, PUSHAM UII, Yogyakarta,

Andi Widjajanto, dkk,Transnasionalisasi Masyarakat Sipil, LKIS, Yogyakarta, 2007

Suparman Marzuki, 2010, Politik Hukum Hak Asasi Manusia

Di Indonesia, Bahan Bacaan Mata Kuliah HAM, Program Magister Ilmu Hukum UII tahun 


\section{Jurnal :}

Sri Hastuti PS, Perlindungan HAM dalam Empat Konstitusi Di Indonesia, Jurnal Magister Hukum No. 1 Vol. 1 Januari 2005, Universitas Islam Indonesia

Pratikno, Keretakan Otoriterisme Orde Baru dan Prospek Demokratisasi, Jurnal Ilmu Sosial Politik, Fisipol UGM, Yogyakarta, Vol. 2 No. 2 November 1998 